\title{
A Statistical Analysis of Morphemes in Japanese Terminology
}

\author{
Kyo KAGEURA \\ National Center for Science Information Systems \\ 3-29-1 Otsuka, Bunkyo-ku, Tokyo, 112-8640 Japan \\ E-Mail: kyo@rd.nacsis.ac.jp
}

\section{Resumen}

En este articulo, esta informado el resultado de análisis estadístico de la dinámica de los elementos constitutivos de términos japoneses. En términos japoneses, la contribución de los elementos morfológicos es diferente según los tipos de origen (entre los elementos adoptados de lenguas occidentales y los elementos originales incluso elementos adoptados de lengua china). Para analizar este punto, un método cuantitativo esta applicado, que puede caracterizar propiamente la dinámica de los datos mofológicos de términos en base a las muestras pequeñas.

\section{概要}

本稿では、日本語専門用語の語種に着目した数量的分析について論ずる。専門用語は言語実態にお いて認められる対象であるため、文の統語構造記述や語の抽象的構造制約記述に相当するような記 述で専門用語の特徵付けを行うことには限界があり、そうした質的分析に基づいて、実態的・量的な 特徵を把握する必要がある。これまで、こうした認識から、語種に着目して専門用語の量的特性を分 析した研究がいくつか見られた。けれども、言語データには、標本に現れない要素が多数存在するた め、与えられた標本を対象とする静的な記述では、その標本に対応する母集団の特性を捉えることが できない。そこで、本稿では、与えられた標本に基づいて同一母集団からの任意の大きさの標本につ いての特性の記述を可能にする数量的モデル（LNRE モデル）を用い、専門用語の語構成要素の動的 な性質を、語種の違いに着目して分析する。

分析の結果、次のことが明らかになった。まず、手法に関しては、用語レベルでの異なりデータに 基づく語構成要素の頻度分布に対して LNRE モデルを適用することが可能であり、実際的に利用可 能な手段として LNRE モデルが非常に有用であることが確認された。次に、語構成要素の語種によ る特性に関しては、外来語は、新規の概念を担う要素としての役割が強いため、延べ頻度での出現が 極端に少ない分野においても、現実的な用語量の範囲で標本量を増やせば、新規出現語の比率が和語 や漢語よりも多くなっていくという傾向が見られた。 